The Silver Mania 


\section{The Silver Mania}

An Exposé of the Causes of High Price Volatility of Silver

by

W. J. Streeter

Chemco Europe, Soest, The Netherlands

\section{Reidel Publishing Company}

A MEMBER OF THE KLUWER ACADEMIC PUBLISHERS GROUP

Dordrecht / Boston / Lancaster 
Library of Congress Cataloging in Publication Data

Streeter, W. J., 1938-

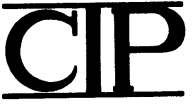

The silver mania.

Bibliography: $\mathrm{p}$.

Includes index.

1. Silver industry. 2. Photographic film industry. 3. SilverPrices. I. Title.

HD9536.A2S77 1984

338.2'3

$84-8373$

ISBN-13:978-94-009-6437-2 e-ISBN-13:978-94-009-6435-8

DOI: $10.1007 / 978-94-009-6435-8$

Published by D. Reidel Publishing Company, P.O. Box 17, 3300 AA Dordrecht, Holland.

Sold and distributed in the U.S.A. and Canada

by Kluwer Academic Publishers,

190 Old Derby Street, Hingham, MA 02043, U.S.A.

In all other countries, sold and distributed

by Kluwer Academic Publishers Group,

P.O. Box 322, 3300 AH Dordrecht, Holland.

All Rights Reserved.

(C) 1984 by D. Reidel Publishing Company, Dordrecht, Holland.

Softcover reprint of the hardcover 1st edition 1984

No part of the material protected by this copyright notice may be reproduced or utilized in any form or by any means, electronic or mechanical including photocopying, recording or by any information storage and retrieval system, without written permission from the copyright owner. 


\section{TABLE OF CONTENTS}

Author's Note vii

Introduction $\quad$ ix

PART I / SILVER MONEY: The History of Silver

Chapter 1/ Early Uses 3

Chapter 2/ The Period of Exploration of America 9

Chapter 3 / The Effect of the Industrial Revolution on Monetary Systems 20

Chapter 4/ Legislated Silver Price 24

PART II / PRECIOUS METALS

Chapter 5/ All Metals Are Precious 43

Chapter 6/ There Are No Precious Metals 44

Chapter 7 / Low Mine Output Metals 48

Chapter $8 /$ Gold and Its Relationship with Silver 54

PART III / SILVER SUPPLY

Chapter 9 / Silver Mine Output 81

Chapter 10 / Secondary Silver 96

PART IV / SILVER USAGE

Chapter 11/ Use Versus Consumption 117

Chapter 12 / Industrial Usage

PART V / PHOTOGRAPHIC SILVER

Chapter 13 / The Photographic Industry 135

Chapter 14 / Color Photography 
Chapter 15 / Radiography 145

Chapter 16/ The Printing Industry 153

Chapter 17 / Other Market Segments 161

Chapter 18 / Silver Recovery in Photography 163

Chapter 19 / Present and Future Usage of Silver in the Photographic Industry

PART VI / SILVER INVESTMENT

Chapter 20 / The Game

Notes

Bibliography

Appendix A: Major Findings and Implications for the Future, from The Price-Responsiveness of Secondary Silver, Bureau of Mines Open File Report 74-82, 1982

Appendix B: Weights: Metric, Troy and Avoirdupois 


\section{AUTHOR'S NOTE}

This book began as a monograph on the use and consumption of silver by the photographic industry. Within the industry itself there has always been a reluctance to disclose production yields and other internal data: information that would reveal exactly the actual net consumption of silver in photography; partly because of this, previously-published accounts have been grossly misleading.

The late 1960's had seen the beginning of an unprecedented upsurge of speculation in silver: the so-called 'silver bulls' fuelled it and the respectable bullion dealers fanned the fires. The mine operators and the middlemen in the partially-underground economy of silver recovery also benefited from the spread of what can only be called the 'silver mania'. Then along came Bunker Hunt with his inherited wealth.

I had begun with the limited intention of showing that silver consumption by the photographic industry in 1982 was only one-fourth of what the silver bulls had predicted as recently as three years earlier; however, the book kept growing, in order to encompass an understanding of the many factors with impact on current silver prices and usage.

Except for my basic study of silver use in photography and the detailed expose of the deceptions practiced by the silver bulls, the rest of the story had already been well presented by other writers. Still it needed to be updated and organized to provide a thorough basis for understanding the state of today's silver market.

This book presents new information and insights into the use of silver in the photographic industry, and key excerpts and digests from a large number of reports and books, most notably the excellent Silver: Economics, Metallurgy and Use, edited by Allison Butts with Charles D. Coxe and sponsored by Handy and Harman (D. van Nostrand and Co., 1967). 
That basic work is frequently cited by the silver bulls, as well as by industry specialists in search of background information. Other major sources are acknowledged in the text where this does not detract from the readability. Further treatment of references is found in the Notes at the end of the book and in the Bibliography.

I have been actively involved in photography since I won a Brownie Reflex camera in a seventh-grade safety contest. I am currently a managing director of European operations for Powers Chemco, Inc., a company specialized in the manufacture of silver halide photographic films for use in the graphic arts. This is an admittedly self-serving book.

I offer no apologies for the polemic style. Photographic manufacturers are high on the long list of innocent victims of the current silver mania. At the top of the list, however, are the purchasers of silver jewelry, photographic materials, silver flatware, electronic products and all the other items whose prices have been inflated to fill the pockets of the silver bulls. That is the largest group of victims.

There are also thousands of former employees of silver-using industries. Silver mania has thrown them out of work into an already recession-ripped economy with high structural unemployment.

I believe that this book had to be written, and it could best be written from inside the photographic industry - previously purported to be the largest industrial consumer of silver and the one with the highest growth rate. This book reveals that photography is not the largest industrial consumer of silver, and shows why its consumption is declining.

If you own a hoard of silver, small or large, and you are determined to hold onto it until the silver price returns to the level at which you purchased, or until your profit dream comes true, then this book is not for you. 


\section{INTRODUCTION}

This is a definitive study of the phenomenon known as Silver Mania. The conclusions can all be stated in a few pages but the underlying facts are carefully presented to provide a basic understanding and to substantiate the conclusions. Most of those afflicted with silver mania are undaunted by facts; they don't want to be persuaded of the reality of things. Speculators do not learn from history, so this study is not for them. It is for the masses who have been innocent victims of silver mania, and who are able in a democratic society to correct injustices.

Silver and gold and copper have a chemical as well as historical relationship. Both silver and gold were scarce until the discovery of silver in the Americas in the 1500's, and the scarcity ratio from pre-1500 is cited by silver bulls as a 'natural price relationship'. During the period that silver was becoming overly abundant it also came into wide usage as a monetary standard and this led to inflation. This was solved by demonetizing silver and the world was thus oversupplied with an attractive metal that was useful only for jewelry and tableware. Silver mines in the United States were the major source of newly-mined silver in the world and the mine operators were able to lobby successfully for legislation to support the price of their product until industrial use started increasing during the 1950's.

By 1960 the U.S. Government had a ridiculously large stockpile of silver, some of which was used for coinage; but with rising industrial usage the coins were being taken out of circulation by speculators faster than they were being minted. That hoarding was the start of silver mania.

During the 1970's silver mania heated up and attracted the attention of the brothers Herbert and Nelson Bunker Hunt, a couple of Texans who were able to collect silver on a grand scale in part because of a tidy inheritance. 
Industrial usage of silver increased but the inflated prices led users to concentrate on using silver more efficiently, and on recycling. While the underground economy masks the magnitude of silver recovery, published data show declining consumption, even though the interpretations by the silver bulls say something else.

In 1979 a combination of silver mania and the unguarded commodities futures exchanges were used to inflate the price of silver to the kinds of levels the silver bulls had been predicting. Like all speculative bubbles, it burst.

That did not put an end, however, to silver mania. The Hunt silver bubble was but an aberration upon an aberration, and silver mania is kept alive by a wide assortment of opportunists. The obvious ones are the silver bulls who sell newsletters and books filled with facts, fictions and distortions, and the active market manipulators such as the Hunt brothers. But there are also the bullion dealers and brokers who encourage silver mania and reap commissions on active trading, and even the financial press which reports unquestioningly the self-serving propaganda of these respected dealers.

That's what keeps the price of silver above $\$ 4.00$ per Troy ounce. 